Int. J. Morphol.,

22(4):297-302, 2004.

\title{
SUBLETHAL DOSES OF MALATHION ALTER MALE REPRODUCTIVE PARAMETERS OF Eisenia foetida
}

\author{
MALATHION EN DOSIS SUBLETALES ALTERA LOS PARÁMETROS \\ REPRODUCTIVOS MASCULINOS DE Eisenia foetida
}

\author{
"Omar Espinoza-Navarro \& **Eduardo Bustos-Obregón
}

\begin{abstract}
ESPINOZA-NAVARRO, O. \& BUSTOS-OBREGÓN, E. Sublethal doses of malathion alter male reproductive parameters of Eisenia foetida. Int. J. Morphol., 22(4):297-302, 2004.
\end{abstract}

SUMMARY:Malathion is an organophosphorate insecticide whose main acute poisonous effect is the inhibition of the enzyme acetylcholinesterase. This pesticide is widely used and has been reported to damage mice spermatogenesis. The objective of this work was to evaluate the toxic risk of malathion, earthworm Eisenia foetida (Annelida, Oligochaeta) like biological model was used and testicles and spermatozoa of animal controls and treaties were analyzed. Earthworms with developed clitellum were used and they were dewed with sublethal single doses of $0,80,150,300$ and $600 \mathrm{mg}$ of malathion for kilogram of soil (LD50 $=880 \mathrm{mg} / \mathrm{kg} \mathrm{dry} \mathrm{soil).} \mathrm{Control}$ groups were added only distilled water. Each group was analyzed 1, 5, 15 and 30 days post treatment. The results observed in treated animals indicate a significant rise of the number of spermatozoa at 1 and 5 days post treatment, followed by a sperm decrease between 15 and 30 days. Acridine orange method showed a significant increase of abnormal metachromatic spermatozoa in treated animals (red fluorescence). Testicular histology of treated animals showed tissue disorganization and vacuolization, with presence of small and hyperchromatic nuclei, indicative of possible apoptosis. It was also found that malathion caused body contraction characterized by coiled tail. Besides significant alteration in count and quality of spermatozoa were seen. Eisenia foetida is then an excellent model to monitor cytotoxic damage of organophosphate pesticides.

KEY WORDS: 1. Eisenia foetida; 2. Malathion; 3. Cytotoxicity; 4. Spermatozoa; 5. Reproductive organs.

\section{INTRODUCTION}

A great amount of toxic substances is present in the environment, which can act by themselves or interact with other substances producing more toxic derivatives. Organophosphorates pesticide act by inhibition of the enzyme acetylcholinesterase, which produces accumulation of acetylcholine, responsible for the clinical manifestations of poisoning (Kwong, 2002). It has been demonstrated that organophophorates increases significantly the index of apoptosis in hepatocytes of CF1 mice (Espinoza et al., 2002) and induces tumors in mammary gland (Cabello et al., 2003). Stromborg (1986) postulated that the chronic ingestion at high doses of these pesticides caused a diminution of food consumption associated to a lack of appetite. According to Atef et al. (1995), in laboratory rats the organophosphorate causes a decrease of testicular mass with degenerative injuries and partial halting of the spermatogenesis and an increase in abnormalities of spermatozoa. Malathion, [(dimethoxyphosphinothioyl) - thio] butanedioic acid diethyl ester, is a non-systemic organo-phosphorate compound, considered as the more innocuous organophosphorate for humans (Golub, 2000), so toxic effect of this pesticide should be monitored.

Routine procedures for evaluation of the risks of the xenobiotics for the human health traditionally have involved testing biological models in mammal (OECD, 1984). Nevertheless, their cost of maintenance is high, the biological cycle and reproductive cycle are long in comparison with other animals. Therefore, there is an increasing interest to look for alternatives to the use of mammals. The election of complementary species should consider physiological analogies and homologies with mammals and ecological relevance. Certain invertebrates have the basic metabolic systems necessary to study the actions of xenobiotics, but with the advantage of being simpler and easier to handle. Earthworms represent the greater fraction of biomass of invertebrates in the ground (> 80\%) and play an important role in structuring and increasing nutrients of grounds and therefore can

\footnotetext{
* Laboratorio de Biología Celular, Reproducción y Desarrollo (BCRD). Universidad de Tarapacá. Arica, Chile.

** Laboratorio Biología de la Reproducción, ICBM. Facultad de Medicina. Universidad de Chile, Santiago, Chile.
} 
successfully be used like bioindicators for the evaluation of toxic risks of xenobiotics in terrestrial ecosystems (Sorour \& Larink, 2001; Bustos-Obregón \& Goicochea 2002). Eisenia foetida belongs to the Phylum Annelida, Class Oligochaeta, is hermaphrodite and fertilizes its eggs inside a quitinous cocoon secreted by the clitellum. The gonadal segments are located in the anterior portion of the worm, between the metameres IX and XV. Spermatogonia are produced in testis, then they are transferred to seminal vesicles grouped as a 4-celled morula where spermatogenesis and spermiogenesis occur. This morula reaches a maximum of 128 germ cells after meiosis, due to their synchronized development. Thus, the testicles in this species are simple organs for renovation of spermatogonia. The clitellum is a reproductive structure characteristic of the oligochaetes, that matures as a secondary sexual gland (Ruppert \& Barnes, 1996).

The objective of this work was to analyze the effect of the insecticide malathion on male reproductive tissue of Eisenia foetida after treatment with 0,80,150,300 y $600 \mathrm{mg}$ of malathion for kilogram of soil (LD50 $=800 \mathrm{mg} / \mathrm{kg}$ of soil) and evaluation at $1,5,15$ and 30 days post treatment, observing coiling of the tail, count and quality of sperm and testicular histology.

\section{MATERIAL AND METHOD}

Eisenia foetida, sexually mature and with developed clitellum, was obtained from local markets (Agricultural "Los Nogales", Paine, Santiago, Chile). They were kept in soil (size of particle $<2 \mathrm{~mm}$ ) with standard feeding (protein $20,5 \%$, fiber $5 \%$, minerals and vitamins and organic matter of vegetable origin), $\mathrm{pH} 6,5$, humidity of $50 \%$ and room temperature between 21 and $22^{\circ} \mathrm{C}$ (Cikutovic et al., 1999). Average weight of the worms was from 0.4 to $0.5 \mathrm{~g}$ before beginning of experiments.

Commercial malathion $(57 \% \mathrm{w} / \mathrm{w})$ from Laboratorios Farmagro S. A., Perú was used.

In order to determine the LD50, 5 groups of treatment were evaluated: 1200, 900, 600, 300 and 150mg malathion / $\mathrm{kg}$ of soil, 40 animals were used per group. This assay was performed twice. Malathion was applied as a single dose at the beginning of the experiment (day 0). Percentage of dead individuals was registered for each dose until the day 14 , settling down therefore the LD50 by kg of dry soil. To determine the effect of the insecticide malathion on male reproductive tissue dose of $0,1 / 10,1 / 6,1 / 3$ and $2 / 3$ of the LD50, were used.
Changes in the external anatomy were made through of coiling of the tail according to the established criteria of Cikutovic et al.

Seminal vesicles were placed in Petri dishes containing $1 \mathrm{ml}$ of PBS (pH 7.4) and cut in small pieces to allow the liberation of the spermatozoa and perform sperm counts using a Neubauer chamber. Counts were expressed as number of spermatozoa per animal.

Pattern of DNA denaturation was evaluated using fluorescent test of acridine orange. Spermatic suspension $\left(1 \times 10^{5}\right.$ spermatozoa each group), was heated at $90^{\circ} \mathrm{C}$ for $10 \mathrm{~min}$. Smears were stained with acridine orange at a final concentration of $0.19 \mathrm{mg} / \mathrm{ml}$ at $\mathrm{pH} 2.5$ for $5 \mathrm{~min}$ in a cold $\left(4^{\circ} \mathrm{C}\right)$ and dark chamber and was observed in a epifluorescence microscope with a 436 nm filter (Zeiss III RS, Germany) (Tejada et al., 1984). Orthochromatic or metachromatic reactions in sperm head are originated when chromatin is highly condensed or decondensed, respectively (Andreetta et al., 1995).

Selected animals were placed in ethanol solution (5\%) and dissected to extract the male reproductive organs, located between the prostomium and the clitellum. For the histological evaluation, male reproductive structures were fixed in aqueous Bouin's solution. Longitudinal and cross sections $(5 \mu \mathrm{m})$ were obtained and stained with the trichromic method of Arteta for their observation in light microscopy. The microscopic evaluation was only carried out in testis.

All results are expressed as mean \pm S.E.M. KruskalWallis and Dunn's multiple comparison post-test were used with the program INSTAT v. 2.04a (GraphPad Software, San Diego, USA). $\mathrm{p}<0.05$ was considered significant.

\section{RESULTS}

LD50 was determined in $800 \mathrm{mg}$ of malathion for kilogram of dry soil. The work doses were $0,80,150,300$ and $600 \mathrm{mg}$ of malathion for kilogram of soil, equivalent to $0,1 / 10,1 / 6,1 / 3$ and $2 / 3$ of the LD50.

Coiled tails were observed in the $100 \%$ of the treated individuals. Control worms did not show this abnormality (Fig. 1).

It was observed that at day 1 there was a significant increase in the number of spermatozoa at doses of 150 and $300 \mathrm{mg}$ of malathion $/ \mathrm{kg}$ of soil. Sperm count showed no significant differences at day 5 in any dose, while a significant decrease was found at 15 and 30 days in the dose of $600 \mathrm{mg}$ of malathion for $\mathrm{kg}$ of soil (Fig.2). 

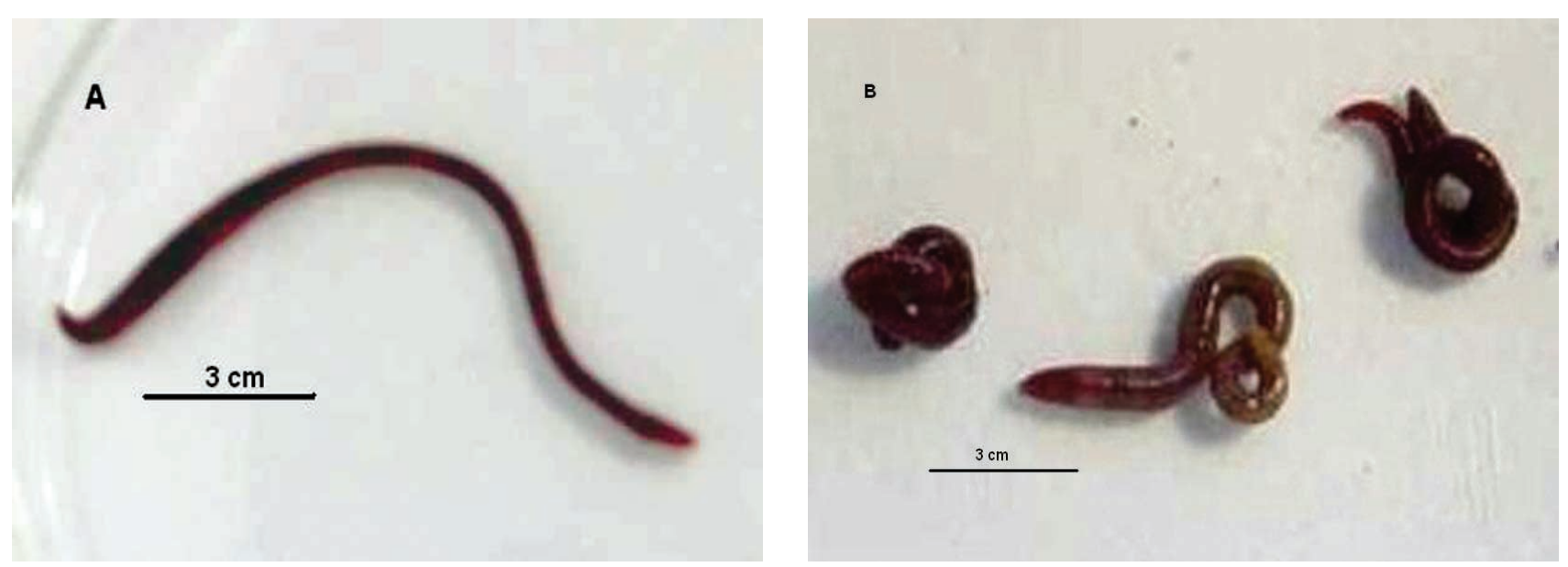

Fig. 1. External morphology of coiling of the tail in E. foetida. In A: Individual control without treatment, tail normal and stretched. B: Animals treated with $600 \mathrm{mg}$ of malathion for $\mathrm{kg}$ of soil and analyzed a day 15 showing coiling of the tail and very contracted.

Fig. 3 shows that malathion increased abnormal spermatozoa nuclear condensation in a dose-dependent manner per day of evaluation. At 1 and 30 days after the treatment a significant increase of metachromasia was observed at doses of 150 and $600 \mathrm{mg}$ of malathion. However this increase of metachromasia is observed in the doses of 300 and $600 \mathrm{mg}$ of malathion at 5 and 15 days of treatment. In controls, normal spermatozoa with high percentage of ortochromasia appeared (green fluorescence). In Figure 4, examples of orthochromatic and metachromatics sperm head are shown.

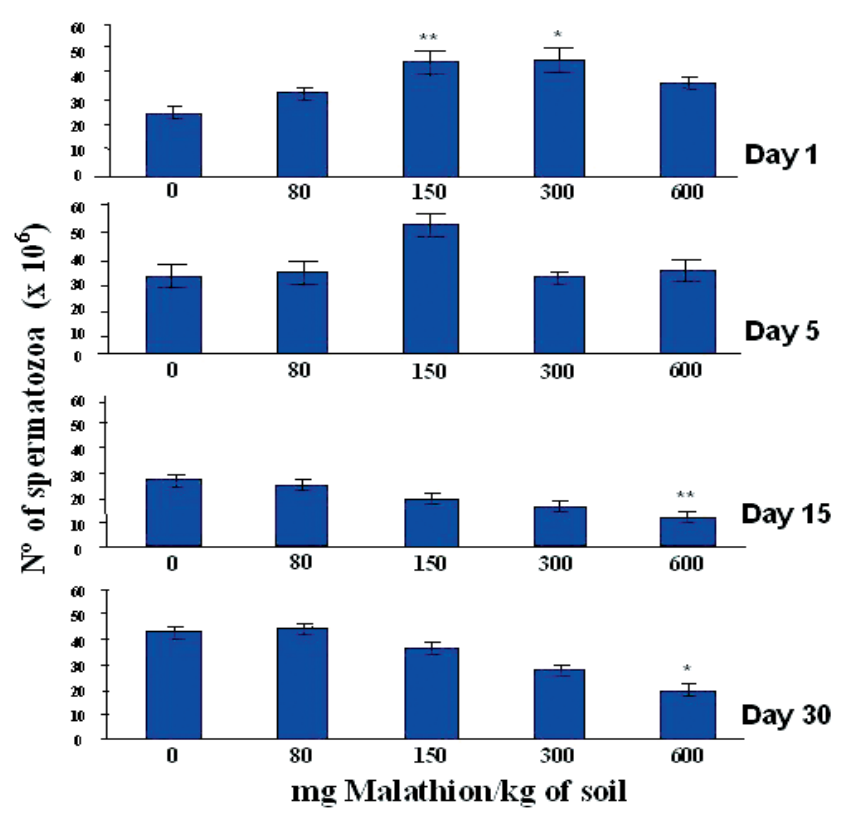

Fig. 2. Sperm count of $E$. foetida treated with $0,80,150,300$, and $600 \mathrm{mg}$ of malathion/ $/ \mathrm{kg}$ of soil and evaluated at days 1, 5, 15 and 30 post treatment. * $\mathrm{P}<0,05 ; * * \mathrm{P}<0,01$.
In control worms, the testicles appear as uniform organs, constituted only by spermatogonias that are associated like groups of morules in the apex of the organ. The base is constituted by spermatogonia of 15 to $20 \mu \mathrm{m}$ in diameter. In treated individuals the testicles showed loss of the central hilus and spermatogonia. The tissue is disordered and with vacuolization. Some of their cells are observed with pyknotic and small nuclei, suggestive of apoptosis. The greater changes are observed by day 15 treatment at dose of $600 \mathrm{mg}$ of malathion for kilogram of soil (Fig 5).

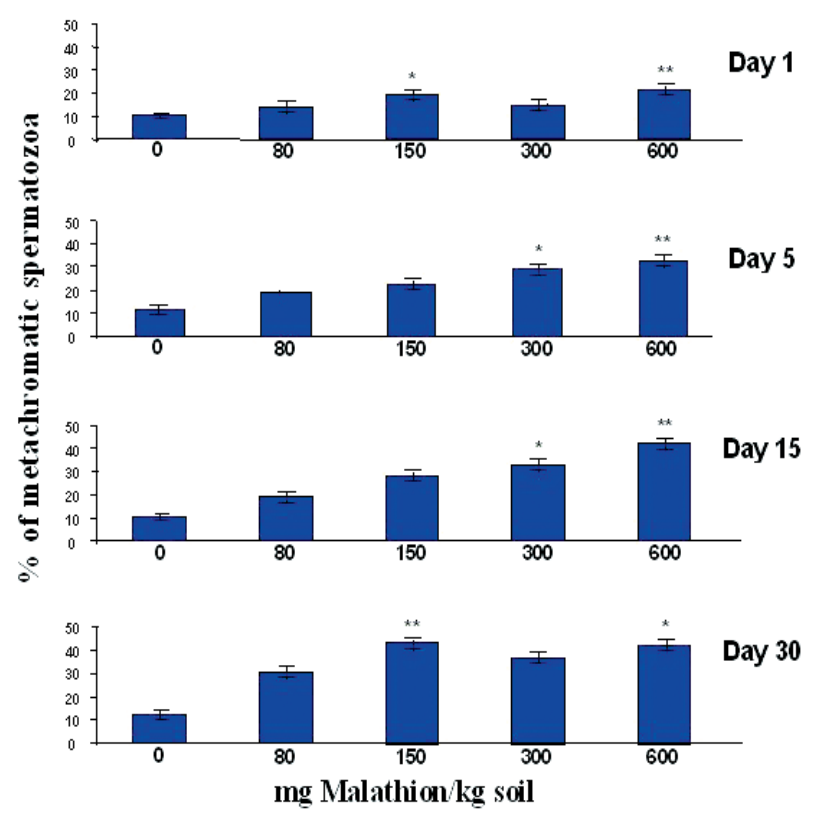

Fig. 3. Percentage of metacromatic spermatozoa of E. foetida treated with $0,80,150,300$ and $600 \mathrm{mg}$ of malathion for $\mathrm{kg}$ of soil and evaluated at days $1,5,15$ and $30 . * \mathrm{P}<0,05 ; * \mathrm{P}<0,001$. 

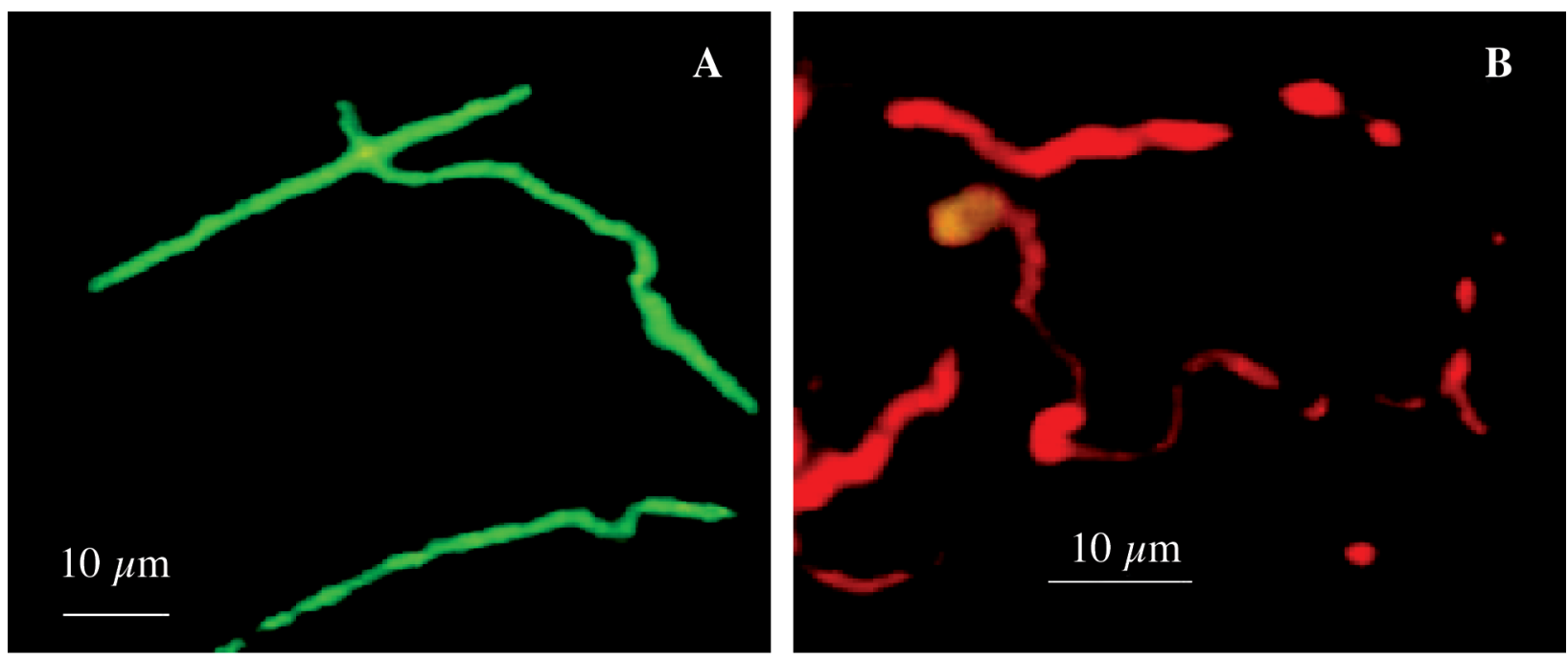

Fig. 4. Normal orthocromatic sperm nuclei, with green fluorescence (A) and metachromatic spermatozoa of E. foetida treated with $600 \mathrm{mg}$ of malathion for kilogram of soil and evaluated at 15 day with red fluorescence (B).
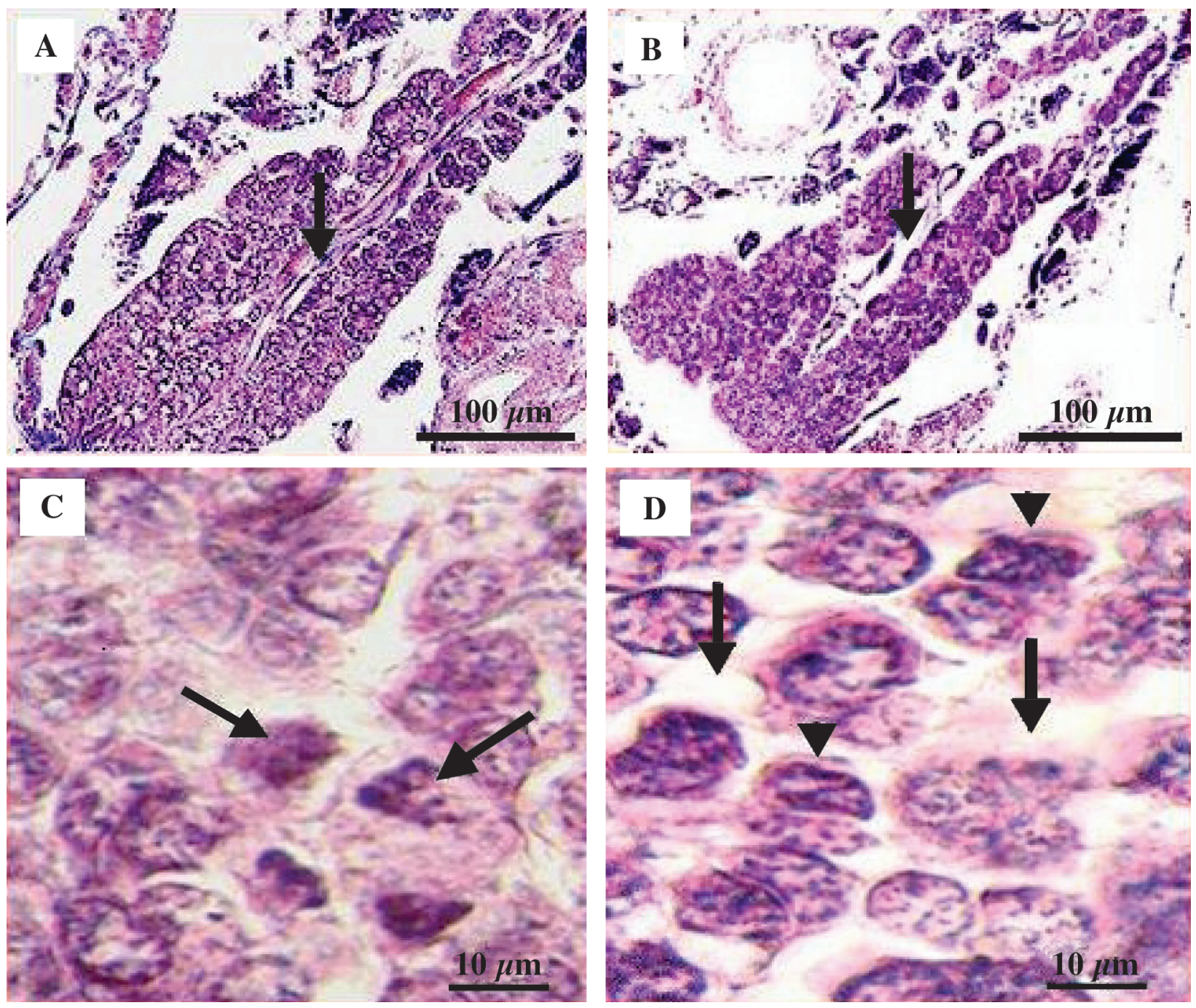

Fig. 5. Testicular histology in control worms and treated with malathion. A: Normal testicle showing a uniform conformation of spermatogonia with a central and well defined hilus (black arrow). B: Testicle of E. foetida treated with $150 \mathrm{mg}$ malathion for $\mathrm{kg}$ of soil and evaluated at day 5 post treatment. Disorganization of the parenchyma and loss of central hilus are observed (black arrow). C: Testicle of control animal, showing a synchronous mitosis (black arrows). D, abnormal testis of a treated animal with $600 \mathrm{mg}$ of malathion and analyzed at day 15, a disordered epithelium and vacuoles are seen (black arrows). The heads of arrow indicates a small pyknotic nucleus, indicative of possible apoptosis (Arteta staining). 


\section{DISCUSSION}

The generalized distribution of chronically non-lethal environmental polluting agents has demonstrated multigenerational effects on the biological systems, altering reproductive, endocrine and immune patterns, changes that can be registered by means of simple organisms that are living in the same ecosystem (Lock et al., 2002; Venkateswara et al., 2003). Malathion has an ample use in agriculture, houses and gardens, and has lethal effects on many living systems. However, little is known about chronic effects of sublethal doses in the reproduction and genetic characteristics of species. Malathion affects the neuromuscular function, altering the balance of $\mathrm{Ca}^{++}$ and $\mathrm{K}^{+}$, which seems to be the factor responsible for changes in the morphology and activity of the earthworms. This would explain the phenomenon of coiling of the tail, observed in all individuals treated with malathion as described earlier. Sperm count evaluation was the more sensitive parameter when determining reproductive alteration in the E. foetida. The increase of spermatozoa in the first day could be explained by the acute effect of malathion on colinergic systems in the reproductive structures of $E$. foetida, which would allow the abnormal escape of stored spermatozoa in spermatheca (Senapati et al., 1992; Bauer \& Rombke, 1997; Bustos-Obregón \& Goicochea).

Other studies report that spermatozoa could be damaged by the effect of the pesticide on spermatogonial morula, altering the ultrastructure of the cytoskeleton of the cytophore (common cytoplasmic mass, anuclear sincitium of the morula), affecting therefore the normal development of the spermatogenesis and the spermiogenesis (Sorour \& Larink). Cabello et al. reported that malathion has a disruptor effect on microfilaments, altering the cytoskeleton of actin. The decrease of the sperm count at 15 and 30 days at dose of $600 \mathrm{mg}$ malathion for $\mathrm{kg}$ of soil possibly indicates that the insecticide has been degraded to its active metabolites malaoxon and isomalathion, which could also alter spermatogenesis (ATSDR, 2000). Blasiak et al. (1999) reported that malathion has an acute and direct cytotoxic effect (cellular death) on human lymphocytes, without causing damage to the DNA, but their active metabolites, malaoxon and isomalathion, could act later by breaking DNA chains. Increases in the number of spermatozoa with abnormalities could be related to the alkylating properties of these insecticides, acting directly on the complex DNA-proteins (Sorour \& Larink; Green et al., 2001). The test of fluorescence with acridine orange, based on the determination of the relation between green orthocromatic fluorescence (normal) and red metachromatic (altered) chromatin, is an adequate test to measure effects of chemical agents on male gametes (Andreetta et al., 1995; Evenson et al., 2002). Therefore, malathion could affect the sperm count, but in addition, its metabolites could affect sperm quality. Testicular histology (Fig. 5) in animals treated with malathion showed a disordered structure with loss of central hilus, vacuolization and cells with small and pyknotics nuclei that could be described as apoptotic process. This could indicate that malathion alter the testicular function seriously in this species, as reported earlier for earthworms and mice treated with organophosphates (Sobarzo \& Bustos-Obregón, 2000; Bustos-Obregón \& González-Hormazábal, 2003).

One concludes that malathion has a direct cytotoxic effect causing coiling of the tail, with increase of metachromasia of the chromatin of the spermatozoa and altering the sperm count. This pesticide also affects testicular structure, with increased vacuolization and hyperpyknosis of the nuclei of spermatogonia. Eisenia foetida is an excellent model to monitor the cytotoxicity of malathion in male reproductive parameters.

Acknowledgements: Research supported by Universidad de Tarapacá (Project No 4760) and Banco Santander Central Hispano (Madrid). We are thankful to M.Sc. Jorge Gutiérrez-Pajares from the Pontificia Universidad Católica de Chile for his critical comments of the manuscript.

ESPINOZA-NAVARRO, O. \& BUSTOS-OBREGÓN, E. Malathion en dosis subletales altera los parámetros reproductivos masculinos de Eisenia foetida. Int. J. Morphol., 22(4):297-302, 2004.

RESUMEN:Malathion es un insecticida organofosforado cuyo efecto agudo principal es la inhibición de la enzima acetilcolinesterasa. Este pesticida es usado ampliamente y se ha informado como dañino para la espermatogénesis de ratones. El objetivo de este trabajo fue evaluar el riesgo tóxico de malathion. Gusano de tierra Eisenia foetida (Annelida, Oligochaeta) se usó como modelo biológico y se analizaron testículos y espermatozoides de animales controles y tratados. Se usaron gusanos de tierra con clitelo desarrollado, los cuales fueron aspersados con dosis sub letales de 0,80,150, 300 y $600 \mathrm{mg}$ de malathion por kilogramo de tierra (LD50 $=880$ $\mathrm{mg} / \mathrm{kg}$ de tierra seca). A los grupos controles se les agregó solo agua destilada. Cada grupo se analizó a los 1, 5, 15 y 30 días post tratamiento. Los resultados observados en los animales tratados indican un alza significativa en el número de espermatozoides a los 1 y 5 días después del tratamiento, seguido por una disminución espermática entre los 15 y 30 días. El uso de naranja de acridina mostró un aumento significativo de espermatozoides metacromáticos anormales en animales tratados (fluorescencia roja). La histología testicular en animales tratados mostró desorganización del tejido y vacuolización, con la presencia de núcleos pequeños e hipercromáticos, indicativo de posible apoptosis. Además, malathion causó contracción corporal caracterizada por la cola enrollada. Se concluye que malathion provoca una alteración significativa en el recuento y en la calidad espermática, en la histología testicular y en la morfología corporal de Eisenia foetida. Este modelo biológico resulta ser excelente para supervisar el daño citotóxico de pesticidas organofosaforados.

PALABRAS CLAVE: 1. Eisenia foetida; 2. Malathion; 3. Citotoxicidad; 4. Espermatozoides; 5. Órganos reproductores. 


\section{REFERENCES}

Andreetta, A.; Stockert, J. \& Barrera C. A simple method to detect sperm chromatin abnormalities: cytochemical mechanism and possible value to predict semen quality in assisted reproductive procedure. Int. J. Androl., 1:23-8,1995.

Atef, M.; Youssef, S.; Ramadan, A.; Nawito, M.; El Sayed, M. \& Abd El Rahman H. Influence of phoxim on testicular and seminal vesicle organs, testosterone and cholinesterase level and its tissue residues in male rats. Deutsch. Tierarztl. Wochenschr., 8:301-5, 1995.

ATSDR (Agency for Toxic Substances and Disease Registry), eds. Malathion; Resumen técnico químico para profesionales de la Salud Pública. Atlanta, Georgia. U.S.A., 2000.

Bauer, C. \& Rombke, A. Factors influencing the toxicity of two pesticides on three Lumbricid species in laboratory test. Soil Biol. Biochem., 29:705-8, 1997.

Blasiak, J.; Jaloszynski, P.; Trzeciaks, A. \& Szyfter, K. In vitro studies on the genotoxicity of the orgaphosphorous insecticide Malathion and its two analogues. Mutat. Res., 445:275-83, 1999.

Bustos-Obregón, E. \& Goicochea, R. Pesticide soil contamination mainly affects earthworm male reproductive parameters. Asian J. Androl., 4:195-9, 2002.

Bustos-Obregón, E. \& González-Hormazábal P. Mice testicular damage elicited by Malathion. Int. J. Morphol. 21:155-9, 2003.

Cabello, G.; Galaz, S.; Botella, L.; Calaf, G.; Pacheco, M.; Stockert, J.; Villanueva, A.; Cañete, M. \& Juarranz, A. The pesticide Malathion induces alteration in actin cytoskeleton and in cell adhesion of cultured breast carcinoma cells. Int. J. Oncol., 23:697-704, 2003.

Cikutovic, MA.; Fitzpatrick, LC.; Goven, AJ.; Venables, BJ.; Giggleman, MA. \& Cooper, EL. Wound healing in earthworms Lumbricus terrestris: a cellular-based biomarker for assessing sublethal chemical toxicity. Bull Environ Contam Toxicol., 62 (4):508-14, 1999.

Espinoza, O.; Bustos-Obregón, E. \& Suja, J. Efecto de parathion sobre los índices de apoptosis en hepatocitos de ratones CF1. Rev. Chil. Anat., 20:29-36, 2002.

Evenson, D.; Larson, K. \& Jost, L. Sperm chromatin structure assay: Its clinical use for detecting sperm DNA fragmentation in male infertility and comparisons with other techniques. J. Androl. 23:25-43, 2002.
Golub, M. Adolescent health and environment. Environ. Health Perspect., 108:355-62. 2000.

Green, G.; Ferlita, R.; Walkenhoorst, W. \& Poccia, D. Linker DNA destabilizes condensed chromatin. Biochem. Cell Biol., 79:349-63, 2001.

Kwong, T. Organophosphate pesticides: Biochemistry and clinical toxicology. Ther. Drug. Monit., 24:144-9, 2002.

Lock,K.; De Schamphelaere, K. \& Janssen, C. The effect of lindane on terrestrial invertebrates. Arch. Environ. Contam. Toxicol., 42:217-221, 2002.

OECD (Organization for Economic Cooperation and Development), eds. Guideline for testing of chemicals $N^{\circ}$ 27. Earthworm acute toxicity test. Paris, France, 1984.

Ruppert, E. \& Barnes, R. Zoología de Invertebrados. Mc GrawHill Interamericana, México, 1996.

Senapati, B.; Beiswa, J.; Pani, S. \& Sahu, S. Ecotoxicological effects of Malathion on earthworms. Soil Biol. Biochem., 24:1719-22, 1992.

Sobarzo, C. \& Bustos-Obregón, E. Acute effect of parathion on the seminiferous epithelium of inmature mice. Rev. Chil. Anat., 18:61-8, 2000.

Sorour, J. \& Larink, O. Toxic effects of benomyl on the ultrastructure during spermatogenesis of the earthworm Eisenia foetida. Ecotoxicol. Environ. Saf., 50:180-8, 2001.

Stromborg, K. Reproductive toxicity of monocrotophos to bobwhite quail. Poultry Sci., 65:51-7, 1986.

Tejada, R.; Cameron, J.; Norman, A.; Marik, J. \& Friedman, S. A test for the practical evaluation of male fertility by acridine orange (AO) fuorescence. Fertil. Steril., 42:87-91, 1984.

Venkateswara, J.; Surya, Y. \& Mahavendra, S. Toxic effects of chlorpyrifos on morphology and acetylcholinesterase activity in the earthworm, Eisenia foetida. Ecotoxicol. Environ. Saf., 54:296-301, 2003.

Correspondence to:

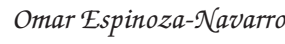

Laboratorio de Biologia Celular, Reproducción y Desarrollo.

Universidad de Tarapací.

General Velasquez 1775. Casilla 7-D.

Arica - CHILE

E-mai: oespinoz@uta.cl

Recibido : 13-05-2004

Aceptado: 24-08-2004 